\title{
Serum Procalcitonin as a Biomarker for the Prediction of Bacterial Exacerbation and Mortality in Severe COPD Exacerbations Requiring Mechanical Ventilation
}

\author{
Begum Ergan ${ }^{a} \quad$ Ahmet Altay Şahin $^{b} \quad$ Arzu Topeli $^{c}$ \\ ${ }^{a}$ Medical Intensive Care Unit, Department of Pulmonary and Critical Care, Faculty of Medicine, Dokuz Eylul \\ University, Izmir, and ${ }^{\mathrm{b}}$ Koru Hospital, and ${ }^{\mathrm{C}}$ Medical Intensive Care Unit, Department of Internal Medicine, Faculty of \\ Medicine, Hacettepe University, Ankara, Turkey
}

\section{Key Words}

Chronic obstructive pulmonary disease exacerbation .

Procalcitonin · Mechanical ventilation · Mortality · Prognosis . Bacterial cause $\cdot$ Etiology $\cdot$ Acute respiratory failure

\begin{abstract}
Background: Procalcitonin (PCT) is being used as a marker of bacterial infections. Although there are several studies showing the diagnostic yield of PCT to differentiate bacterial involvement in chronic obstructive pulmonary disease exacerbations (COPDE), the prognostic yield of PCT in severe COPDE has been studied less. Objectives: The primary aim was to determine whether the level of serum PCT at admission in severe COPDE serves as a prognostic biomarker for hospital mortality. The secondary aim was to determine the role of PCT in identifying a bacterial exacerbation. Methods: A total of 63 COPDE patients (median age 71 years; male $58.7 \%$ ) were retrospectively analyzed from our intensive care unit database. Results: The hospital mortality rate was $23.8 \%$. Admission PCT levels were higher in patients who died during hospitalization ( 0.66 vs. $0.17 \mathrm{ng} / \mathrm{ml} ; \mathrm{p}=0.014$ ). This association between hospital mortality and serum PCT level remained significant in a multivariate analysis; for every $1 \mathrm{ng} / \mathrm{ml}$ increase in PCT level, hospital mortality increased 1.85 times (odds ratio; $95 \%$ confidence interval: 1.07-3.19; $\mathrm{p}=0.026$ ). The optimal admission PCT threshold was 0.25
\end{abstract}

$\mathrm{ng} / \mathrm{ml}$ in order to discern patients who had bacterial exacerbation with a sensitivity of $63 \%$, a specificity of $67 \%$, and a negative predictive value of $80 \%$. The negative predictive value increased to $89 \%$ when both the admission and followup PCT levels remained $<0.25 \mathrm{ng} / \mathrm{ml}$. Conclusion: This study shows that admission PCT levels have a prognostic importance in estimating hospital mortality among patients with severe COPDE. A PCT level $<0.25 \mathrm{ng} / \mathrm{ml}$ at the time of admission and during follow-up is suggestive of the absence of a bacterial cause of COPDE.

(c) 2016 S. Karger AG, Basel

\section{Introduction}

Chronic obstructive pulmonary disease (COPD) is one the major causes of morbidity and mortality among respiratory diseases. COPD exacerbations (COPDE), which are known to show as a sudden worsening of symptoms, cause the main disease burden [1-4]. Typically, viral and/or bacterial infections are thought to be the main cause of COPDE, but most of the time bacteria can be identified in only one third of the cases [5-9]. Starting

This study was presented as a poster at the American Thoracic Society 2010 International Conference, New Orleans, La., USA.

\section{KARGER}

E-Mail karger@karger.com

www.karger.com/res
C 2016 S. Karger AG, Basel

0025-7931/16/0914-0316\$39.50/0 
antibiotic therapy for COPDE is still controversial; especially if COPDE are severe and present with respiratory failure, it is advised to use antibiotics for 7-10 days $[1,10]$. This, however, may cause overtreatment, side effects, an increase in bacterial resistance, and last but not least high costs in these patients [11-13].

Procalcitonin (PCT) is a 116-amino-acid peptide and is produced in response to endotoxin and other mediators released in bacterial infections. It is accepted as a 'bacterial infection' biomarker in many systemic infections, including lower respiratory tract infections and COPDE [14-18]. Recently, PCT has been used to guide antibiotic therapy, and it can be safely used to reduce inappropriate antibiotic prescription in COPDE $[17,19,20]$. However, there are limited data on PCT-guided antibiotic therapy in more severe COPDE cases that require mechanical ventilation and intensive care unit (ICU) admission [21, 22].

PCT has been shown to be not only a diagnostic biomarker for bacterial infections but also accepted as a prognostic predictor of short- and long-term mortality in lower respiratory tract infections [18, 23]. High PCT levels were reported to be related to increased morbidity and mortality in many patient populations such as those with pneumonia and severe sepsis [23-26].

The present study was primarily conducted to determine whether the level of serum PCT at admission in severe COPDE serves as a prognostic biomarker for hospital mortality. The secondary aim was to determine the role of PCT in identifying bacterial exacerbation.

\section{Patients and Methods}

\section{Study Population}

The study was conducted in a 9-bed medical ICU of a tertiary university hospital. The local ethics committee approved the study. The ICU database was screened for COPDE between May 1, 2007, and July 31, 2009, and all patients with a history of COPD diagnosed by the Global Initiative for Chronic Obstructive Lung Disease (GOLD) criteria (age $>40$ years, $>10$ pack-years of smoking, or biomass history) were included into the study. The exclusion criteria were: (1) clinical and radiological suspicion for an alternative cause of respiratory failure, such as pulmonary embolism, pneumonia, severe sepsis, congestive heart failure, or acute respiratory distress syndrome; (2) staying in the ICU for $<24 \mathrm{~h}$, and (3) no PCT level available within $24 \mathrm{~h}$ of admission.

Demographic characteristics such as age, gender, smoking history, COPD severity according to the GOLD classification [1], preadmission pulmonary function test values (if available), the presence of comorbidities, use of domiciliary oxygen and noninvasive ventilation (NIV), hospital admission due to COPDE within the previous year, antibiotic use prior to hospitalization, Acute Physiology and Chronic Health Evaluation (APACHE) II score [27], and Glasgow Coma Scale (GCS) score were recorded.

\section{Laboratory Workup}

Admission arterial blood gas analysis, white blood cell count, serum C-reactive protein, and PCT levels $\left(\mathrm{PCT}_{1}\right)$ were recorded. If present, a second follow-up PCT was recorded as $\mathrm{PCT}_{2}$. Serum PCT was determined using a quantitative immunoassay (BRAHMS PCT sensitive KRYPTOR; BRAHMS, Henningsdorf, Germany). The assay's functional sensitivity was described previously [28]. For PCT levels, we used previously defined cutoff values $(0.1,0.25$, and $0.5 \mathrm{ng} / \mathrm{ml}$ ) for respiratory tract infections [16].

\section{Microbiologic Analysis of Respiratory Tract Infection}

According to our clinical practice, all patients were evaluated for microbiological confirmation following admission to the ICU. All nonintubated patients were asked to give sputum samples. For patients who could not give a sputum sample but had secretions, tracheal aspiration was performed; for intubated patients, microbiological analysis of the respiratory tract was done either by endotracheal aspiration or mini-bronchoalveolar lavage. Bacterial infection was confirmed if there were $>10^{6}$ colony-forming units (CFU) in a sputum sample, $>10^{5} \mathrm{CFU}$ in endotracheal/tracheal aspirate, and $10^{4} \mathrm{CFU}$ in the mini-bronchoalveolar lavage. Changes in antibiotic treatment after the microbiological results were also recorded.

Data Collection for Mechanical Ventilation and Follow-Up

All patients had acute respiratory failure and were supported by either invasive ventilation (mechanical ventilation with intubation) or NIV. The degree of hypoxemia, initial mechanical ventilation support type, duration, failure in NIV, the lengths of ICU and hospital stays, as well as ICU and hospital mortality rates were evaluated.

\section{Statistical Analysis}

The primary outcome of the study was whether the PCT level on admission predicted hospital mortality in severe COPDE, and the secondary outcome was the possible diagnostic yield of PCT for a bacterial exacerbation.

All categorical variables are expressed as percentages, and continuous variables are expressed as medians and interquartile ranges. Categorical variables were compared between groups with the $\chi^{2}$ or Fisher's exact test; continuous variables were compared with the Mann-Whitney U test. The independent effect of serum PCT level on hospital mortality was assessed with a logistic regression model; the backward elimination method was used to overcome overfitting in the model. PCT levels for hospital mortality were assessed with areas under the receiver operating characteristic curve, and predictive PCT cutoff levels were selected according to the previous literature $(0.1,0.25$, and $0.5 \mathrm{ng} / \mathrm{ml}[16])$. A p value of $<0.05$ was considered as statistically significant. Statistical analysis was performed with SPSS version 17.0.

\section{Results}

A total of 63 patients with COPDE (median age 71 years; male $58.7 \%$ ) were included in the study. The study flowchart is presented in figure 1 , and the patient characteristics are shown in table 1 . Most of the patients had severe COPD and were using oxygen at home (56\%). 
Fig. 1. Study flowchart according to initial


ventilatory support and primary outcom

Table 1. General characteristics of the study population

\begin{tabular}{lc}
\hline Patients & 63 \\
Male gender & $37(58.7)$ \\
Age, years & $71.0(62.0-78.0)$ \\
Previous smoking history/active smoking & $44(69.8) / 9(14.3)$ \\
$\quad$ Pack-years & $50.0(21.3-77.5)$ \\
Severity of COPD & \\
$\quad$ GOLD stage III & $9(14.3)$ \\
$\quad$ GOLD stage IV & $42(66.7)$ \\
Long-term oxygen therapy & $35(55.6)$ \\
Domiciliary NIV & $3(4.8)$ \\
Comorbidities & \\
$\quad$ Hypertension & $40(63.5)$ \\
$\quad$ Congestive heart failure & $20(31.7)$ \\
$\quad$ Coronary artery disease & $18(28.6)$ \\
$\quad$ Diabetes mellitus & $17(27.0)$ \\
Chronic renal disease & $5(7.9)$ \\
$\quad$ Malignancy & $5(7.9)$ \\
$\quad$ Benign prostate hyperplasia & $5(7.9)$ \\
Hospitalization within previous year & $30(47.6)$ \\
Antibiotic use prior to hospitalization & $33(52.4)$ \\
GCS score & $15(13-15)$ \\
APACHE II score & $20(17-23)$ \\
Predicted mortality according to & \\
$\quad$ APACHE II score & $27.6(19.7-37.1)$ \\
\end{tabular}

All values are expressed as numbers (percentages) or medians (IQR). ${ }^{a}$ Pulmonary function tests were not available in 12 patients.
The clinical characteristics of the patients during their ICU stay are presented in table 2. All patients had respiratory failure, with a median ratio of partial arterial oxygen pressure to the fraction of inspired oxygen $\left(\mathrm{PaO}_{2} / \mathrm{FIO}_{2}\right)$ of 152.5 , and were receiving mechanical ventilation. Initial support was invasive mechanical ventilation in 29 cases (46.0\%) and NIV in 34 cases (54.0\%), but 9 patients (14.3\%) failed to respond to initial NIV support. The median total duration of mechanical ventilation was 6 days [interquartile range (IQR) 3-13], and the median length of ICU and hospital stay was 9 days (IQR 5.5-15.0) and 14 days (IQR 10.0-27.0), respectively.

The median $\mathrm{PCT}_{1}$ for the whole patient population was $0.22 \mathrm{ng} / \mathrm{ml}$ (IQR 0.08-0.58). Fifty-one patients had $\mathrm{PCT}_{2}$, and the median value was $0.22 \mathrm{ng} / \mathrm{ml}$ (IQR $0.09-$ 0.52 ). Twenty-seven patients had both $\mathrm{PCT}_{1}$ and $\mathrm{PCT}_{2}$ $<0.25 \mathrm{ng} / \mathrm{ml}$.

\section{PCT as a Predictor of Mortality in COPDE}

The hospital mortality rate was $23.8 \%(\mathrm{n}=15)$. Statistically significant factors for survivors and nonsurvivors are presented in table 3 . When statistically significant variables related to hospital mortality were put into a model for multivariate analysis, the relationship between hospital mortality and $\mathrm{PCT}_{1}$ level remained significant 
Table 2. Clinical characteristics of the study population during ICU stay $(n=63)$

\begin{tabular}{|c|c|}
\hline \multicolumn{2}{|l|}{ Mechanical ventilation support } \\
\hline Invasive & $29(46.0)$ \\
\hline Noninvasive & $34(54.0)$ \\
\hline Noninvasive failure & $9(14.3)$ \\
\hline Duration of mechanical ventilation, days & $6.0(3.0-13.0)$ \\
\hline \multicolumn{2}{|l|}{ Admission arterial blood gas values } \\
\hline $\mathrm{pH}$ & $7.32(7.26-7.44)$ \\
\hline $\mathrm{PaCO}_{2}, \mathrm{~mm} \mathrm{Hg}$ & $60(46.0-79.5)$ \\
\hline $\mathrm{PaO}_{2}, \mathrm{~mm} \mathrm{Hg}$ & $71.0(55.8-94.5)$ \\
\hline $\mathrm{PaO}_{2} / \mathrm{FIO}_{2}$ & $152.5(124.5-196.4)$ \\
\hline $\mathrm{HCO}_{3}, \mathrm{mEq} / \mathrm{l}$ & $32.9(26.0-36.0)$ \\
\hline \multicolumn{2}{|l|}{ Positive respiratory tract bacterial } \\
\hline culture $^{\mathrm{a}}$ & $16(25.4)$ \\
\hline White blood cell count, $\times 10^{3} / \mu \mathrm{l}$ & $10.4(7.7-13.0)$ \\
\hline C-reactive protein, $\mathrm{mg} / \mathrm{dl}$ & $6.3(2.9-9.8)$ \\
\hline $\mathrm{PCT}_{1}, \mathrm{ng} / \mathrm{ml}$ & $0.22(0.08-0.58)$ \\
\hline $\mathrm{PCT}_{1} \geq 0.25 \mathrm{ng} / \mathrm{ml}$ & $36(57.1)$ \\
\hline $\mathrm{PCT}_{2}{ }^{\mathrm{b}}, \mathrm{ng} / \mathrm{ml}$ & $0.22(0.09-0.52)$ \\
\hline $\mathrm{PCT}_{2} \geq 0.25 \mathrm{ng} / \mathrm{ml}$ & $24(38.1)$ \\
\hline Length of ICU stay, days & $9.0(5.5-15.0)$ \\
\hline Length of hospital stay, days & $14.0(10.0-27.0)$ \\
\hline ICU mortality & $9(14.3)$ \\
\hline Hospital mortality & $15(23.8)$ \\
\hline
\end{tabular}

All values are expressed as numbers (percentages) or medians (IQR). $\mathrm{HCO}_{3}=$ Bicarbonate; $\mathrm{PaCO}_{2}=$ partial pressure of carbon dioxide. ${ }^{\mathrm{a}} \mathrm{n}=52 .{ }^{\mathrm{b}} \mathrm{n}=51$.

(table 4). For every $1 \mathrm{ng} / \mathrm{ml}$ increase in $\mathrm{PCT}_{1}$ level, hospital mortality increased 1.85 times [odds ratio; $95 \%$ confidence interval (CI): 1.07-3.19; $\mathrm{p}=0.026] . \mathrm{PCT}_{2}$ level and decrease in PCT were not related to mortality.

\section{PCT as a Predictor of Bacterial COPDE}

Microbiological cultures of the respiratory tract were obtained from 52 patients (82.5\%). Eleven nonintubated patients could not provide samples good enough for evaluation. Sixteen patients (30.8\%) had significant bacterial growth (2 patients had growth of multiple bacteria in one specimen culture). The distribution of the positive cultures of the respiratory tract is as follows: Escherichia coli $(\mathrm{n}=4)$, Pseudomonas aeruginosa $(\mathrm{n}=4)$, Acinetobacter baumannii $(\mathrm{n}=3)$, Moraxella catarrhalis $(\mathrm{n}=2)$, Haemophilus influenzae $(\mathrm{n}=2)$, Streptococcus pneumoniae $(\mathrm{n}=1)$, Klebsiella pneumoniae $(\mathrm{n}=1)$, methicillin-sensitive Staphylococcus aureus ( $\mathrm{n}=1)$, and methicillin-resistant $S$. aureus $(\mathrm{n}=1)$. Differences between respiratory tract culture-positive and-negative patients are shown in table 5. $\mathrm{PCT}_{1}$ levels were similar between the two groups; however, $\mathrm{PCT}_{2}$ levels, obtained a median of 3 days after admission, were significantly higher in culture-positive patients ( 0.52 vs. $0.18 \mathrm{ng} / \mathrm{ml} ; \mathrm{p}=0.012$ ).

Antibiotic therapy was not appropriate for 10 patients due to the narrow spectrum $(n=5)$ or the presence of multiresistant bacteria $(n=5)$. These patients had median $\mathrm{PCT}_{1}$ levels similar to those of the rest of the patients $[0.41$ $\mathrm{ng} / \mathrm{ml}$ (IQR 0.09-2.44) vs. $0.20 \mathrm{ng} / \mathrm{ml}$ (IQR 0.08-0.41); $\mathrm{p}=0.251]$. PCT levels were similar between patients who used antibiotics prior to hospitalization and those who did not [data not shown; median levels $0.22 \mathrm{ng} / \mathrm{ml}$ (IQR $0.09-0.50)$ vs. $0.21 \mathrm{ng} / \mathrm{ml}$ (IQR 0.07-0.65); $\mathrm{p}=0.973$ ].

The diagnostic accuracies of $\mathrm{PCT}_{1}$ alone as well as of $\mathrm{PCT}_{1}$ and $\mathrm{PCT}_{2}$ used together in predicting culture growth are summarized in table 6 . The optimal $\mathrm{PCT}_{1}$ threshold was $0.25 \mathrm{ng} / \mathrm{ml}$ for differentiating patients with and those without any bacterial culture growth, with a sensitivity of $63 \%$ and a specificity of $67 \%$ (fig. 2). At this threshold, the negative predictive value was $80 \%$. The sensitivity and specificity for both $\mathrm{PCT}_{1}$ and $\mathrm{PCT}_{2}$ levels $\geq 0.25 \mathrm{ng} / \mathrm{ml}$ in identifying patients with bacterial culture growth was $87 \%$ and $59 \%$, respectively. Therefore, if $\mathrm{PCT}_{1}$ is $<0.25 \mathrm{ng} / \mathrm{ml}$, the probability for a negative culture result is $80 \%$. The negative predictive value for absence of bacterial growth in culture increased to $89 \%$ when both the $\mathrm{PCT}_{1}$ and the $\mathrm{PCT}_{2}$ level remained $<0.25 \mathrm{ng} / \mathrm{ml}$ (fig. 3 ).

\section{Discussion}

This study showed that the $\mathrm{PCT}_{1}$ level has a prognostic importance in estimating hospital mortality among patients with severe COPDE. In addition, a PCT level $<0.25$ $\mathrm{ng} / \mathrm{ml}$ at the time of admission and during follow-up is suggestive of the absence of a bacterial cause of COPDE.

\section{PCT and Mortality}

The primary aim of this study was to find out the predictive value of PCT with regard to hospital mortality among severe COPDE patients admitted to the ICU with the need for mechanical ventilatory support, and the study showed that nonsurvivors had higher $\mathrm{PCT}_{1}$ levels. For every $1 \mathrm{ng} / \mathrm{ml}$ increase in $\mathrm{PCT}_{1}$ level, hospital mortality increased 1.85 times. In another study, high serum PCT levels had been related to bacteremia and higher disease severity scores (pneumonia severity index and CURB-65 score), longer hospitalization, treatment failure, and mortality in pneumonia [29]. Previous studies also showed that high PCT levels were associated with severity in critically ill patient populations [24, 30-32]. In patients suf- 
Table 3. Statistically significant factors related to hospital mortality (bivariate analysis)

\begin{tabular}{lccc}
\hline & $\begin{array}{l}\text { Nonsurvivors } \\
(\mathrm{n}=15)\end{array}$ & $\begin{array}{l}\text { Survivors } \\
(\mathrm{n}=48)\end{array}$ & $\mathrm{p}$ \\
\hline GCS score & $13(9-15)$ & $15(14-15)$ & 0.020 \\
Invasive mechanical ventilation & $12(80.0)$ & $17(35.4)$ & 0.003 \\
Duration of mechanical ventilation, days & $10.0(7.0-14.0)$ & $5.0(3.0-9.5)$ & 0.020 \\
Length of ICU stay, days & $14.0(8.0-20.0)$ & $8.5(5.2-13.0)$ & 0.044 \\
$\mathrm{PCT}_{1}, \mathrm{ng} / \mathrm{ml}$ & $0.66(0.20-2.00)$ & $0.17(0.08-0.38)$ & 0.014 \\
$\mathrm{PCT}_{1} \geq 0.25 \mathrm{ng} / \mathrm{ml}$ & $10(66.6)$ & $17(35.4)$ & 0.008 \\
\hline
\end{tabular}

All values are expressed as numbers (percentages) or medians (IQR).

Table 4. Multivariate logistic regression analysis of independent predictors of hospital mortality

\begin{tabular}{llll}
\hline & Odds ratio & $95 \%$ CI & $\mathrm{p}$ \\
\hline PCT $_{1}$ & 1.85 & $1.07-3.19$ & 0.026 \\
GCS score & 0.75 & $0.59-0.96$ & 0.025 \\
\hline
\end{tabular}

Table 5. Bivariate analysis of patients with positive and negative microbiological culture results

\begin{tabular}{lccc}
\hline & $\begin{array}{l}\text { Culture positive } \\
(\mathrm{n}=16)\end{array}$ & $\begin{array}{l}\text { Culture negative } \\
(\mathrm{n}=36)\end{array}$ & $\mathrm{p}$ \\
\hline Hospitalization within the last year & $9(56.2)$ & $15(41.7)$ & 0.330 \\
Previous antibiotic use & $9(56.2)$ & $18(50.0)$ & 0.677 \\
Invasive mechanical ventilation & $14(87.5)$ & $22(61.1)$ & 0.102 \\
Duration of mechanical ventilation, days & $9.5(2.8-15.5)$ & $6.0(3.0-10.0)$ & 0.432 \\
Length of ICU stay, days & $13.7(7.6-20.0)$ & $8.0(5.3-13.0)$ & 0.061 \\
Length of hospital stay, days & $25.0(12.0-37.0)$ & $13.5(9.8-22.8)$ & 0.058 \\
ICU mortality $_{\text {Hospital mortality }}^{4(25.0)}$ & $5(13.9)$ & 0.431 \\
White blood cell count, $\times 10^{3} / \mu \mathrm{l}$ & $6(37.5)$ & $8(22.2)$ & 0.252 \\
$\mathrm{C}_{-}$reactive protein, $\mathrm{mg} / \mathrm{dl}$ & $11.0(9.0-12.4)$ & $9.8(8.0-13.0)$ & 0.532 \\
PCT $_{1}$, ng/ml & $7.3(4.0-8.7)$ & $5.3(2.1-10.4)$ & 0.678 \\
PCT $_{2}{ }^{2}$, ng/ml & $0.41(0.12-0.99)$ & $0.18(0.07-0.37)$ & 0.076 \\
\hline
\end{tabular}

All values are expressed as numbers (percentages) or medians (IQR). ${ }^{a} \mathrm{n}=51$.

Table 6. Diagnostic accuracy of $\mathrm{PCT}_{1}$ alone and of $\mathrm{PCT}_{1}$ and $\mathrm{PCT}_{2}$ used together in identifying culture growth

\begin{tabular}{lllllll}
\hline & AUC $(95 \% \mathrm{CI})$ & Sn & Sp & PPV & NPV & LR \\
\hline $\mathrm{PCT}_{1} \geq 0.25 \mathrm{ng} / \mathrm{ml}$ & $0.65(0.49-0.82)^{*}$ & 0.63 & 0.67 & 0.45 & 0.80 & 1.9 \\
$\mathrm{PCT}_{1}$ and $\mathrm{PCT}_{2} \geq 0.25 \mathrm{ng} / \mathrm{ml}$ & $0.73(0.57-0.88)^{* *}$ & 0.87 & 0.59 & 0.52 & 0.89 & 2.1 \\
\hline
\end{tabular}

AUC = Area under the curve; $\mathrm{LR}=$ likelihood ratio; NPV = negative predictive value; $\mathrm{PPV}=$ positive predictive value; $\mathrm{Sn}=$ sensitivity; $\mathrm{Sp}=$ specificity. ${ }^{*} \mathrm{p}=0.081 ;{ }^{* *} \mathrm{p}=0.015$. 




Fig. 2. Receiver operating characteristic curve for $\mathrm{PCT}_{1}$ level and bacterial culture growth. The optimal cutoff value for $\mathrm{PCT}_{1}$ for differentiating patients with and those without any bacterial culture growth was $0.25 \mathrm{ng} / \mathrm{ml}$ [area under the curve 0.65 (95\% CI: 0.49$0.82 ; \mathrm{p}=0.081]$; the sensitivity and specificity for $\mathrm{PCT}_{1} \geq 0.25 \mathrm{ng} /$ $\mathrm{ml}$ in identifying patients with bacterial culture growth was 63 and $67 \%$, respectively.

fering from ventilator-associated pneumonia, serum PCT levels could predict death and septic shock [33].

Although there are several studies showing the diagnostic yield of PCT for bacterial COPDE, the prognostic yield of PCT for COPDE has been studied less. Moreover, there are limited data on the predictive role of PCT in severe COPDE-related death in the ICU setting. There are two studies performed on patients with severe COPDE followed up in an ICU. Rammaert et al. [22] found that among intubated COPDE patients, $63 \%$ of nonsurvivors had PCT values $>0.24 \mathrm{ng} / \mathrm{ml}$, whereas a lower percentage of survivors (38\%) had high PCT values. In that study, the hazard ratio for PCT was 1.02 (95\% CI: 1.00-1.03) for ICU mortality. In another study done on a severe COPDE cohort, nonsurvivors had high PCT levels; however, the number of patients was too small $(n=4 / 35)$ to obtain conclusive results [21].

In a recent meta-analysis done by Kutz et al. [34], the prognostic yield of PCT was evaluated in all types of acute respiratory tract infection. A subgroup analysis showed that PCT level was a good indicator of mortality in COPDE, with an adjusted odds ratio of 6.12 (95\% CI: 2.46-15.18; $\mathrm{p}<0.001)$. Moreover, this study also showed that increased PCT levels had a higher positive predictive value for mortality among ICU patients. All these data suggest that higher $\mathrm{PCT}_{1}$ levels might be related to increased risk of death in severe COPDE. We think that admission PCT levels might serve as a prognostic factor for

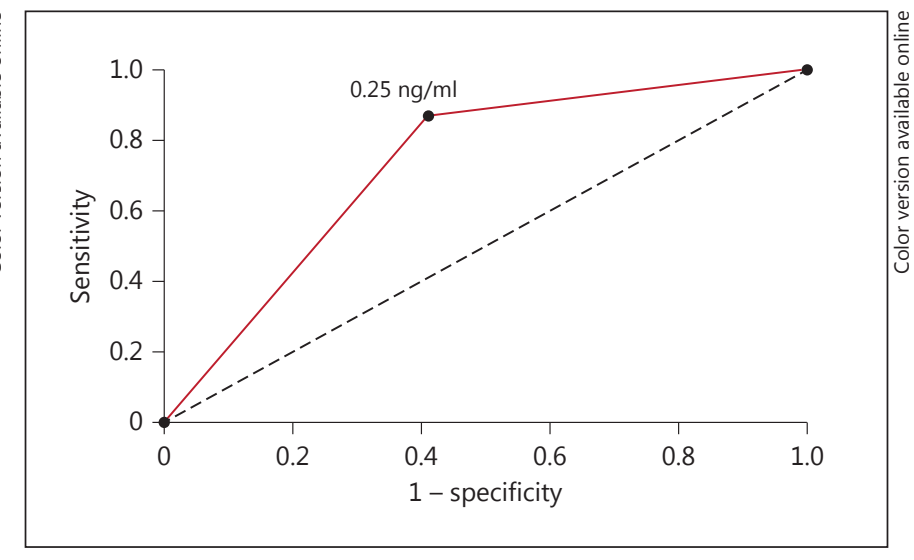

Fig. 3. Receiver operating characteristic curve for $\mathrm{PCT}_{1}$ and $\mathrm{PCT}_{2}$ levels and bacterial culture growth. Area under the curve: 0.73 (95\% CI: 0.57-0.88); $\mathrm{p}=0.015$. The sensitivity and specificity for $\mathrm{PCT}_{1}$ and $\mathrm{PCT}_{2}$ levels $\geq 0.25 \mathrm{ng} / \mathrm{ml}$ in identifying patients with bacterial culture growth was 87 and 59\%, respectively.

risk stratification in severe COPDE patients who require ICU admission due to the need of ventilatory support.

\section{PCT Clearance and Mortality}

Another approach to predicting mortality is clearance of PCT. Changes in PCT levels in response to therapeutic treatment have also been reported, which suggests a prognostic significance in a variety of clinical settings [35-38]; however, in this study $\mathrm{PCT}_{2}$ measurements and changes in PCT levels did not have any significance in predicting death. This might be for the following reasons: (1) only 51 patients had a $\mathrm{PCT}_{2}$ measurement, and (2) the percentage of inappropriate antibiotic therapies was relatively low (15.8\%).

\section{PCT and Bacterial COPDE}

COPDE can be precipitated by several factors, but the most suspected cause appears to be infections. Although bacterial cultures from the respiratory tract might be positive in COPD patients during exacerbations, studies have also shown that many patients, especially those who have more severe COPD, have colonization in the airways during the stable phase $[7,39,40]$. Because of these factors, the use of antibiotics for the treatment of COPDE is still a controversial issue in mild-to-moderate exacerbations; severe exacerbations, however, are exceptional, since the use of antibiotics in this case is the safer and more preferred approach $[1,12,41]$. 
Nonetheless, a study evaluating severe COPDE reported that only half of the patients had bacterial growth [42]. Overuse of antibiotics might result in adverse events, development of resistant strains, longer ICU/hospital stays, and higher costs. Therefore, having another parameter that helps the clinician to decide whether to start or withhold antibiotics is of great value. PCT is produced in response to endotoxin and other mediators released in bacterial infections. PCT-guided antibiotic therapy has been shown to be effective and safe in many infectious conditions and various clinical settings and could therefore also be used in the management of severe COPDE in the ICU [43].

Although in this study $\mathrm{PCT}_{1}$ levels were slightly higher in culture-positive patients $[0.41 \mathrm{ng} / \mathrm{ml}(0.12-0.99)$ vs. $0.18 \mathrm{ng} / \mathrm{ml}(0.07-0.37)]$, this difference did not reach statistical significance. This might be for a couple of reasons. First, previous antibiotic use might have been beneficial in a subgroup of culture-positive patients, which might have caused a lower PCT response. Second, this might reflect an early phase of infection, since the $\mathrm{PCT}_{2}$ measurements in the culture-positive group were significantly higher than those in the culture-negative group. Third, both groups had relatively small numbers of patients that might fail to show any statistically significant difference.

Another important finding in this study is the significantly higher $\mathrm{PCT}_{2}$ level in culture-positive patients. Out of 16 patients with positive culture result, 10 had inappropriate antibiotic therapy due to either use of narrowspectrum antibiotics or infection with multiresistant strains. This was an unexpected finding in our study. Although treatment is usually switched to a wider-spectrum antibiotic when a patient develops acute respiratory failure, this might still be inadequate in some severe COPD cases. We think that, as previously reported, rising PCT levels could be used as a treatment failure biomarker in severe COPDE.

In our study, we found that $\mathrm{PCT}_{2}$ levels remained lower in patients who had no bacterial growth in their respiratory tract specimen. The optimal $\mathrm{PCT}_{1}$ cutoff was determined to be $0.25 \mathrm{ng} / \mathrm{ml}$, with a negative predictive value of $80 \%$ for identifying patients with bacterial culture growth. If both the $\mathrm{PCT}_{1}$ and $\mathrm{PCT}_{2}$ levels remained $<0.25$ $\mathrm{ng} / \mathrm{ml}$, the negative predictive value increased to $89 \%$. In this study, all patients were on antibiotic therapy, and 27 patients had both PCT levels $<0.25 \mathrm{ng} / \mathrm{ml}$. Using PCT for guidance in these patients would lead to a $43 \%$ decreased use of antibiotics by ruling out the presence of a bacterial exacerbation.
Our results are in concordance with previous studies which evaluated the utility of PCT for determining the presence of bacterial exacerbations. In a study done in hospitalized COPDE patients, $76 \%$ had antibiotic therapy, but if the threshold of PCT $<0.25 \mathrm{ng} / \mathrm{ml}$ had been used, treatment would have been given to only $7 \%$ of them [28]. Nseir et al. [44] reported that PCT $>0.5 \mathrm{ng} / \mathrm{ml}$ with a positive Gram stain for endotracheal aspirate was associated with bacterial exacerbations. In a multicenter randomized controlled study from Italy, the authors compared 10 days of antibiotic treatment with discontinuation of antibiotics within 3 days plus PCT guidance in patients hospitalized for COPDE [20]. It was found that discontinuing antibiotics on day 3 with PCT $<0.25$ $\mathrm{ng} / \mathrm{ml}$ was a safe method, and there was no difference between the groups for outcomes such as exacerbation rate, hospital/ICU admission functional status decline, and mortality within a 6-month period. An important point in this study was that the authors did not use PCT guidance and continued antibiotics in patients with respiratory failure. However, we think that our results support the usefulness of PCT as an additional parameter in any decision to discontinue antibiotics in this subgroup of patients as well.

On the other hand, there are other studies with contradictory results. A study conducted by Daniels et al. [45] showed that there was no relationship between PCT and bacterial exacerbations. Additionally, treatment with doxycycline showed benefits in patients with low PCT levels. In a study of community-acquired pneumonia, initial PCT levels provided only moderate prognostic information concerning mortality risk and did not improve clinical risk scores [46]. Hence, although it seems to be safe to use PCT as guidance in antibiotic therapy, we still think that it is just an additional parameter to consider.

\section{Other Factors Found to Be Related to Mortality}

In our study, a low GCS score was also independently related to hospital mortality. We already know that poor neurologic status and a low GCS score are associated with NIV failure in COPDE cases [47]. Most of such patients need intubation, which has been shown to result in worse morbidity and mortality compared with NIV. Likewise, and as expected, in our study bivariate analysis showed that nonsurvivors had needed invasive mechanical ventilation more often, even though multivariate analysis showed that invasive mechanical ventilation was not an independent risk factor for hospital mortality. Therefore, we think that NIV failure could explain the effect of GCS score on mortality in this study population. 


\section{Limitations and Strengths of the Study}

Our study has some limitations. First, it is a retrospective single-center study. However, the data were extracted from a prospectively collected database in which the data were collected in a meticulous and continuous pattern and were updated during patient follow-up. Second, about half of the patients had had antibiotics prior to ICU admission, which might be a factor that could affect our results. Previous antibiotic use was around 50\%, and this of course might have influenced microbiological status and, therefore, $\mathrm{PCT}_{1}$ values. However, there was no difference in either the level of PCT or the mortality rate between patients who used antibiotics prior to hospitalization and those who did not. A similar result was also reported in the study by Daubin et al. [21], where one third of the study population had used antibiotics prior to admission but this was not related to PCT levels as well. Real-life experience tells us that most of severe COPDE patients seek help before hospitalization; therefore, it is not rare for them to have had antibiotic therapy prior to hospital or even ICU admission.

We think that there are some important strengths of our study. First, it was performed on severe COPDE patients who required ICU admission. Most PCT studies in the literature evaluated prognosis mostly in mild-tomoderate COPDE either in the emergency room or the hospital ward $[17,19,20]$. Second, the study included patients with severe COPD, mostly GOLD stages III and IV. Our results give very important clues as to the management of this fragile subgroup of patients. In this patient population, the incidence of bacterial exacerbations is ex- pected to be high; therefore, most of these patients are treated with antibiotics in routine practice. We, on the other hand, think that these patients benefit most from the diagnostic yield of PCT. Last but not least, we included all patients who needed mechanical ventilation (either invasive or noninvasive). The only prognostic PCT study performed in the ICU setting included only intubated COPDE patients [22]. As NIV is currently considered the first-line treatment of COPDE-related respiratory insufficiency, our results might apply to a greater percentage of patients for prediction of prognosis.

\section{Conclusions}

This study highlights two important results: (1) high $\mathrm{PCT}_{1}$ levels might be related to higher mortality rates in COPDE patients who require either invasive or noninvasive mechanical ventilatory support, and (2) $\mathrm{PCT}_{1}$ and $\mathrm{PCT}_{2}$ levels $<0.25 \mathrm{ng} / \mathrm{ml}$ might be helpful in excluding bacterial exacerbation with a $89 \%$ confidence and might be used as an additional parameter for a shorter duration of antibiotic treatment in these patients. The effectiveness of PCT guidance for antibiotic therapy in severe COPDE should be evaluated in prospective randomized clinical trials.

\section{Financial Disclosure and Conflicts of Interest}

None declared.

\section{References}

1 NHLBI/WHO Global Initiative for Chronic Obstructive Lung Disease (GOLD): Global strategy for the diagnosis, management and prevention of chronic obstructive pulmonary disease (updated 2015). http://www.goldcopd.com.

2 Donaldson GC, Seemungal TA, Bhowmik A, Wedzicha JA: Relationship between exacerbation frequency and lung function decline in chronic obstructive pulmonary disease. Tho$\operatorname{rax} 2002 ; 57: 847-852$.

-3 Miravitlles M, Murio C, Guerrero T, Gisbert R; DAFNE Study Group: Pharmacoeconomic evaluation of acute exacerbations of chronic bronchitis and COPD. Chest 2002;121:14491455.

4 Connors AF Jr, Dawson NV, Thomas C, Harrell FE Jr, Desbiens N, Fulkerson WJ, Kussin P, Bellamy P, Goldman L, Knaus WA: Outcomes following acute exacerbation of severe chronic obstructive lung disease. The SUPPORT Investigators (Study to Understand Prognoses and Preferences for Outcomes and Risks of Treatments). Am J Respir Crit Care Med 1996;154:959-967.

5 Wedzicha JA, Seemungal TA: COPD exacerbations: defining their cause and prevention. Lancet 2007;370:789-796.

6 White AJ, Gompertz S, Stockley RA: Chronic obstructive pulmonary disease. 6 . The aetiology of exacerbations of chronic obstructive pulmonary disease. Thorax 2003;58:73-80.

7 Sethi S, Sethi R, Eschberger K, Lobbins P, Cai X, Grant BJ, Murphy TF: Airway bacterial concentrations and exacerbations of chronic obstructive pulmonary disease. Am J Respir Crit Care Med 2007;176:356-361.

-8 Papi A, Bellettato CM, Braccioni F, Romagnoli M, Casolari P, Caramori G, Fabbri LM,
Johnston SL: Infections and airway inflammation in chronic obstructive pulmonary disease severe exacerbations. Am J Respir Crit Care Med 2006;173:1114-1121.

9 Sethi S, Evans N, Grant BJ, Murphy TF: New strains of bacteria and exacerbations of chronic obstructive pulmonary disease. N Engl J Med 2002;347:465-471.

10 Stolz D, Tamm M: Discriminate use of antibiotics for exacerbation of COPD. Curr Opin Pulm Med 2000;15:126-132.

11 Miravittles M: Do we need antibiotics for treating exacerbations of COPD? Ther Adv Respir Dis 2007;1:61-76.

12 Vollenweider DJ, Jarrett H, Steurer-Stey CA, Garcia-Aymerich J, Puhan MA: Antibiotics for exacerbation of chronic obstructive pulmonary disease. Cochrane Database Syst Rev 2012;12:CD010257. 
$\checkmark 13$ Gotfried M, Busman TA, Norris S, Notario GF: Role of 5-day, once-daily extended release clarithromycin in acute bacterial exacerbation of chronic bronchitis. Curr Med Res Opin 2007;23:459-466.

14 Tang BM, Eslick GD, Craig JC, McLean AS: Accuracy of procalcitonin for sepsis diagnosis in critically ill patients: systematic review and meta-analysis. Lancet Infect Dis 2007;7:210217.

$\checkmark 15$ Boussekey N, Leroy O, Alfandari S, Devos P, Georges H, Guery B: Procalcitonin kinetics in the prognosis of severe community-acquired pneumonia. Intensive Care Med 2006;32: 469-472.

-16 Christ-Crain M, Jaccard-Stolz D, Bingisser R, Gencay MM, Huber PR, Tamm M, Müller B: Effect of procalcitonin-guided treatment on antibiotic use and outcome in lower respiratory tract infections: cluster-randomized single-blinded intervention trial. Lancet 2004; 363:600-607.

17 Schuetz P, Christ-Crain M, Thomann R, Falconnier C, Wobers M, Widmer I, Niedert S, Fricker T, Blum C, Schild U, Regez K, Schoenenberger R, Henzen C, Bregenzer T, Hoess C, Krause M, Bucher HC, Zimmerli W, Mueller B; ProHOSP Study Group: Effect of procalcitonin-based guidelines vs standard guidelines on antibiotic use in lower respiratory tract infections: the ProHOSP randomized controlled trial. JAMA 2009;302:1059-1066.

18 Christ-Crain M, Müller B: Biomarkers in respiratory tract infections: diagnostic guides to antibiotic prescription, prognostic markers and mediators. Eur Respir J 2007;30:556-573.

-19 Stolz D, Christ-Crain M, Bingisser R, Leuppi J, Miedinger D, Müller C, Huber P, Müller B, Tamm M: Antibiotic treatment of exacerbations of COPD: a randomized, controlled trial comparing procalcitonin guidance with standard therapy. Chest 2007;131:9-19.

-20 Verduri A, Luppi F, D’Amico R, Balduzzi S, Vicini R, Liverani A, Ruggieri V, Plebani M, Barbaro MP, Spanevello A, Canonica GW, Papi A, Fabbri LM, Beghe B; FARM58J2XH Study Group: Antibiotic treatment of severe exacerbations of chronic obstructive pulmonary disease with procalcitonin: a randomized noninferiority trial. PLoS One 2015 10:e0118241.

-21 Daubin C, Parienti JJ, Vabret A, Ramakers M, Fradin S, Terzi N, Freymuth F, Charbonneau P, du Cheyron D: Procalcitonin levels in acute exacerbation of COPD admitted to ICU: a prospective cohort study. BMC Infect Dis 2008;8:145-153.

-22 Rammaert B, Verdier N, Cavestri B, Nseir S: Procalcitonin as a prognostic factor in severe exacerbations of chronic obstructive pulmonary disease. Respirology 2009;14:969-974.

-23 Horie M, Ugajin M, Suzuki M, Noguchi S, Tanaka W, Yoshihara H, Kawakami M, Kichikawa Y, Sakamoto Y: Diagnostic and prognostic value of procalcitonin in community-acquired pneumonia. Am J Med Sci 2012;343:30-35.
24 Bloos F, Marshall JC, Dellinger RP, Vincent JL, Gutierrez G, Rivers E, Balk RA, Laterre PF, Angus DC, Reinhart K, Brunkhorst FM: Mul tinational, observational study of procalcitonin in ICU patients with pneumonia requiring mechanical ventilation: a multicenter observational study. Crit Care 2011;15:R88.

25 Liu D, Su L, Han G, Yan P, Xie L: Prognostic value of procalcitonin in adult patients with sepsis: a systematic review and meta-analysis. PLoS One 2015; 10:e129450.

26 Kenzaka T, Okayama M, Kuroki S, Fukui M, Yahata S, Hayashi H, Kitao A, Kajii E, Hashimoto M: Use of a semiquantitative procalcitonin kit for evaluating severity and predicting mortality in patients with sepsis. Int J Gen Med 2012;5:483-488.

27 Knaus WA, Draper EA, Wagner DP, Zimmerman JE: APACHE II: a severity of disease classification system. Crit Care Med 1985;13: 818-829.

28 Bafadhel M, Clark TW, Reid C, Medina MJ, Bathan S, Barer MR, Nicholson KG, Brightling CE: Procalcitonin and C-reactive protein in hospitalized adult patients with community-acquired pneumonia or exacerbation of asthma or COPD. Chest 2011;139:14101418 .

29 Berg P, Lindhardt BO: The role of procalcitonin in adult patients with communityacquired pneumonia. Dan Med J 2012: 59:A4353.

30 Giamarellos-Bourboulis EJ, Mega A, Grecka P, Scarpa N, Koratzanis G, Thomopoulos G, Giamarellou H: Procalcitonin: a marker to clearly differentiate systemic inflammatory response syndrome and sepsis in the critically ill patient? Intensive Care Med 2002;28:13511356.

31 Ramírez P, Ferrer M, Martí V, Reyes S, Martínez R, Menéndez R, Ewig S, Torres A: Inflammatory biomarkers and prediction for intensive care unit admission in severe community-acquired pneumonia. Crit Care Med 2011;39:2211-2217.

32 Kibe S, Adams K, Barlow G: Diagnostic and prognostic biomarkers of sepsis in critical care. J Antimicrob Chemother 2011;66(suppl 2):ii33-ii40

33 Hillas G, Vassilakopoulos T, Plantza P, Rasidakis A, Bakakos P: C-reactive protein and procalcitonin as predictors of survival and septic shock in ventilator-associated pneumonia. Eur Respir J 2010;35:805-811.

-34 Kutz A, Briel M, Christ-Crain M, Stolz D, Boudma L, Wolff M, Kristoffersen KB, Wei L, Burkhardt O, Welte T, Schroeder S, Nobre V, Tamm M, Bhatnagar N, Bucher HC, Luyt CE, Chastre J, Tubach F, Mueller B, Schuetz P: Prognostic value of procalcitonin in respiratory tract infections across clinical settings. Crit Care 2015; 19:74-85.

35 Schuetz P, Maurer P, Punjabi V, Desai A, Amin DN, Gluck E: Procalcitonin decrease over 72 hours in US critical care units predicts fatal outcome in sepsis patients. Crit Care 2013;17:R115.
36 Mat Nor MB, Md Ralib A: Procalcitonin clearance for early prediction of survival in critically ill patients with severe sepsis. Crit Care Res Pract 2014;2014:819034.

37 Luyt CE, Guerin V, Combes A, Trouillet JL, Ayed SB, Bernard M, Gibert C, Chastre J: Procalcitonin kinetics as a prognostic marker of ventilator-associated pneumonia. Am J Respir Crit Care Med 2005;171:48-53.

38 Tanriverdi H, Tor MM, Kart L, Altın R, Atalay F, Sümbüloğlu V: Prognostic value of serum procalcitonin and C-reactive protein levels in critically ill patients who developed ventilator associated pneumonia. Ann Thorac Med 2015;10:137-142.

-39 Miravitlles M, Espinosa C, Fernández-Laso E, Martos JA, Maldonado JA, Gallego M: Relationship between bacterial flora in sputum and functional impairment in patients with acute exacerbations of COPD. Study Group of Bacterial Infection in COPD. Chest 1999;116: 40-46.

40 Sethi S, Murphy TF: Bacterial infection in chronic obstructive pulmonary disease in 2000: a state-of-the-art review. Clin Microbiol Rev 2001;14:336-363.

41 Miravitlles M: Is it possible to reduce the use of antibiotics in severe exacerbations of chronic obstructive pulmonary disease? Respiration 2008;76:249-250

42 Stolz D, Tamm M: Discriminate use of antibiotics for exacerbation of COPD. Curr Opin Pulm Med 2009;15:126-132.

43 Schuetz P, Albrich W, Mueller B: Procalcitonin for diagnosis of infections and guide to antibiotic decisions: past, present and future. BMC Med 2011;9:107.

44 Nseir S, Cavestri B, Di Pompeo C, Diarra M, Brisson $H$, Lemyze $M$, Roussel-Delvallez $M$, Durocher A: Factors predicting bacterial involvement in severe acute exacerbations of chronic obstructive pulmonary disease. Respiration 2008;76:253-260.

-45 Daniels JM, Schoorl M, Snijders D, Knol DL, Lutter R, Jansen HM, Boersma WG: Procalcitonin vs C-reactive protein as predictive markers of response to antibiotic therapy in acute exacerbations of COPD. Chest 2010; 138:1108-1115.

-46 Schuetz P, Suter Widmer I, Chaudri A, Christ-Crain M, Zimmerli W, Mueller B; Procalcitonin-Guided Therapy and Hospitalisation in Patients with Lower Respiratory Tract Infections (ProHOSP) Study Group: Prognostic value of procalcitonin in communityacquired pneumonia. Eur Respir J 2011;37: 384-392.

47 Confalonieri M, Garuti G, Cattaruzza MS, Osborn JF, Antonelli M, Conti G, Kodric M, Resta O, Marchese S, Gregoretti C, Rossi A; Italian Noninvasive Positive Pressure Ventilation (NPPV) Study Group: A chart of failure risk for noninvasive ventilation in patients with COPD exacerbation. Eur Respir J 2005; 25:348-355. 